\title{
First cigarette smoking experience among secondary-school students in Aden, Republic of Yemen
}

\author{
A.A. Bawazeer, 'A.S. Hattab' and E.Morales'
}

$$
\text { أمين أحمد باوزير وعبد الله سعيد حطاب الأولى بين طلاب المدارس الئانوية في عدن، بجمهورية اليمن }
$$

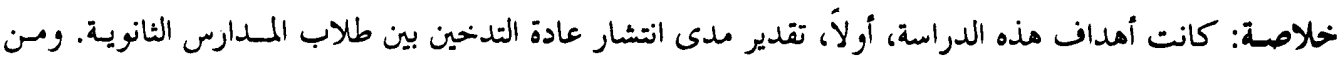

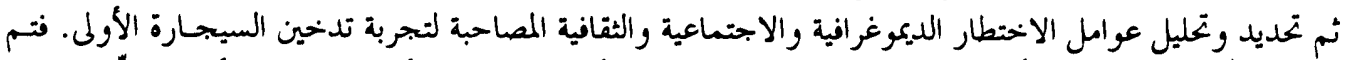

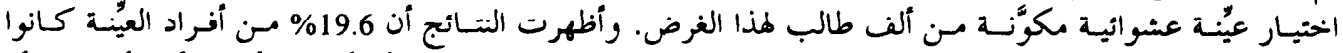

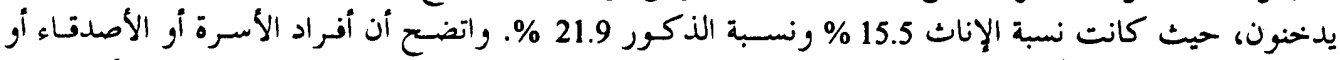

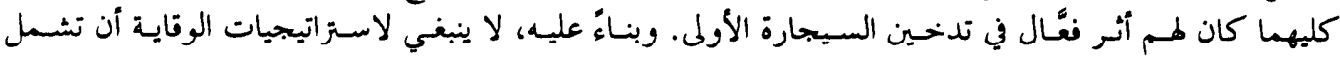

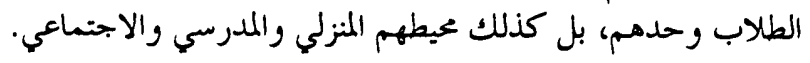

ABSTRACT The objectives of this study were first to estimate the prevalence of cigarette smoking among secondary-school students and then to identify and analyse the demographic, social and cultural risk factors associated with the first cigarette smoking experience. A sample comprising 1000 students was selected randomly. Results showed that $19.6 \%$ of the total sample smoked; $15.5 \%$ among females and $21.9 \%$ among males. Family and/or friends appeared to influence the first cigarette experience and thus prevention strategies should involve not only the students themselves but the home, school and social environments also.

\section{L'expérience de la première cigarette chez les élèves du secondaire à Aden (République du Yémen)}

RESUME Les objectifs de cette étude étaient en premier lieu d'estimer la prévalence de l'usage de la cigarette parmi les élèves du secondaire et ensuite d'identifier et d'analyser les facteurs de risque démographiques, sociaux et culturels qui sont associés à l'expérience de la première cigarette. Un échantillon composé de 1000 élèves du secondaire a été sélectionné au hasard. Les résultats ont montré que $19,6 \%$ des personnes comprises dans l'échantillon total fumaient, le pourcentage étant de $15,5 \%$ chez les filles et de $21,9 \%$ chez les garçons. La famille et/ou les amis semblaient influer sur l'expérience de la première cigarette, et les stratégies de prévention devraient donc concerner non seulement les élèves du secondaire mais aussi le milieu familial, scolaire et social.

'Department of Community Medicine and Public Health, Faculty of Medicine, Aden University, Aden, Republic of Yemen.

Received: 25/4/98; accepted: 09/08/98 


\section{Introduction}

The world consumption of cigarettes is estimated at around six hundred billion cigarettes per year. That total number of cigarettes is enough to send 3 million smokers to the grave annually; this includes both passive and active smokers. Smoking is becoming one of the important mortality risk factors, not only in industrialized countries but also in developing countries. Great efforts have been made to reduce the number of smokers in industrialized countries; for example the percentage of the population that smokes in England has been reduced to $9 \%$ and in United States to $25 \%$. However, the number of smokers has been increasing in developing countries. The percentage of the population who are smokers is about $22 \%$ in the Asiatic countries and $42 \%$ in the African communities [1].

Although the hazards of smoking are well known, the number of smokers among school students is still high. There are many factors influencing these students to start smoking; for example, socioeconomic status, parents, friends and siblings who smoke, and social environment [2]. Research in industrialized countries has repeatedly stressed the importance of preventing tobacco use among young people. In developing countries, however, smoking among children and adolescents has not received as much attention [3]. Nonetheless, it is well known that smoking among adolescents is a developmental phenomenon with several factors exerting an influence on cigarette use at different times [4]. Cigarette smoking is considered to be the single most preventable contributor to chronic diseases, but there is still controversy about the initiation and maintenance of smoking among adolescents [5].
Currently, there are more than 70 countries in the world which have official antismoking programmes and activities, including campaigns to protect individuals from tobacco smokers and promote a healthy environment. Work environments and other public places should be tobaccosmoke free in order to reduce the adverse effect on the people's health [6]. In response to international anti-smoking campaigns, the National Authority in the Republic of Yemen passed a resolution on community protection from smoking, which indicated in its general view the absolute prohibition of smoking in public places, including public transportation. However, it still has not been strictly implemented.

In the Republic of Yemen, the problem of smoking has not yet been investigated comprehensively, although some preliminary studies have been performed in some regions covering limited population groups. During 1991, a school-based study was carried out in Sirra District (Aden Governorate), which found that $7.1 \%$ of the total number of students of the secondary schools were smokers [7]. Another study on chewing khat and its associated habits showed that cigarette smoking was very common among khal-chewers. The study was carried out in 1992 among medical students of different grades in the Faculty of Medicine, Aden University and the results showed that $42 \%$ of khat-chewers were also smokers. Of these, $9.3 \%$ only smoked when they were chewing khat leaves [8].

Tobacco is cultivated in the country in limited areas; in Hadhramout (southern part) and in Tohamma (northern part). However, this tobacco is not used for the local manufacturing of cigarettes by the two cigarette companies; they only use imported tobacco. The local tobacco is usual- 
ly used in different forms of consumption; for example, chewing it with the green leaves of pan (locally called tumbol), in the shisha pipe where the inhaling tube is commonly shared by a group of smokers and as snuff, although this last use is not widespread.

Our study aimed to investigate the smoking habits of secondary-school students, with particular reference to the first experience of cigarette smoking in order to provide some useful recommendations to reduce this habit among our youth. Our objectives were to:

- estimate the prevalence of cigarette smoking among secondary-school students according to sex;

- describe the first experience of cigarette smoking among ever-smoker secondary-school students (ever-smoker refers to those who smoke regularly and those who have only tried smoking);

- identify some demographic, psychosocial and familial factors associated with smoking among secondary-school students.

\section{Subjects and methods}

This descriptive study was performed in April 1997 in Aden Governorate, Republic of Yemen. The study population was secondary-school students attending classes during the study period. A sample of 1000 students was randomly chosen applying a two-stage stratified cluster sampling, where each school was considered as a cluster. Stratification was by scx, school level and district in order to assure a representative sample according to the data available in the Office for Education in Aden.
At the first stage, and based on the number of students according to the register in the Office for Education in Aden, the proportion of the students by sex in the three directorates of Aden (Al-Meena, Seera, Al-Shab) was determined. The total sample size was fixed at 1000 students from the beginning and this total figure was distributed proportionally by sex, school level and directorate. To select the students, a second stage was used; that is the selection of schools. Two schools in each directorate were selected by simple random sampling and the sample size for that district was proportionally divided between the total number of students in each school. The students were given a questionnaire and a $100 \%$ response rate was obtained using systematic sampling inside the school, i.e. if one student refused to participate, another was chosen.

The study was carried out with the full cooperation of the different levels of authority in the Local Office for Education and the school managers and written permission was sought from the Office.

An anonymous, closed, self-administered questionnaire was used for the data collection, which was completed by all those included in the sample. During data collection, teachers were requested to be out of the classroom thus giving more assurance of confidentiality.

Data were analysed using Microstat system. Chi-squared and hypothesis tests for difference of percentages were applied with a significance level of $5 \%$, and $95 \%$ confidence intervals were calculated.

\section{Results and discussion}

The sample studied comprised $64.5 \%$ males and $35.5 \%$ females. Among all students studied the smoking prevalence was 
$19.6 \% ; 21.9 \%$ among males and $15.5 \%$ among females (Table 1). The difference was statistically significant $(P<0.05)$. The $95 \%$ confidence intervals of the estimated smoking prevalence for secondary-school students in Aden Governorate are: all students 17.1-22.1; males 20.3-23.5; females 13.6-17.4.

Jarallah and colleagues from Saudi Arabia reported a lower smoking prevalence rate among male junior secondary-school students (13.2\%) [9]. Higher rates have been reported in the United States and New Zealand $(52 \%$ and $65 \%$ respectively) $[10,11]$. These differences could be explained by the different social and cultural conditions prevailing in different communities.

The most common age for starting smoking was between 15 years and 19 years among all ever-smokers, followed by 10-14 years and under 10 years (Table 2). The pattern was similar for both sexes, although among females the proportion of those who started smoking between 10 years and 14 years was significantly higher than in males. It was found that $56.4 \%$ of female ever-smokers started at 14 years or less while $58.2 \%$ of male ever-smokers started at 15 years or more; thus females

Table 1 Prevalence of smoking among secondary-school students by sex, Aden Governorate, Republic of Yemen, 1997

\begin{tabular}{lccccccc}
\hline Smoking & \multicolumn{2}{c}{ Males } & \multicolumn{2}{c}{ Females } & \multicolumn{2}{c}{ Total } \\
& No. & $\%$ & No. & $\%$ & No. & $\%$ \\
\hline Smokers & 111 & 21.9 & 55 & 15.5 & 196 & 19.6 \\
Never & & & & & & \\
$\quad$ smoked & 504 & 78.1 & 300 & 84.5 & 804 & 80.4 \\
Total $^{\text {a }}$ & 645 & 64.5 & 355 & 35.5 & 1000 & 100.0
\end{tabular}

a Percentage calculated from the total of the row. The rest of the percentages calculated from the total of the column. seem to start smoking at significantly younger ages than males $\left(\chi^{2}=6.299, P<\right.$ 0.05 ).

Generally the prevalence of ever-smoking increased with the age. Similar results have been reported from China where smoking prevalence increased with age among boys and from Italy where smoking began among 11-13-year-old children and increased exponentially with age $[12,13]$.

Considering all ever-smokers, the main sources of the first cigarette were relative/ neighbour $(25 \%)$, school friend $(18.9 \%)$ and friend outside school (18.9\%) (Table 3). Close relatives, i.e. father, mother or sibling, accounted for $20.9 \%$ if taken together. Teachers represented $2.6 \%$. Similar findings have been reported from Indonesia and China [2,3]. By sex, the situation is completely different (Table 3 ). Among females, close relatives (father, mother, sibling) as the source of the first cigarette constituted a significantly higher proportion than males. Among males, school friends and friends outside school as the sources of the first cigarette constituted a significantly higher proportion.

The first cigarette for those who started smoking before 10 years of age was predominantly given by a relative/neighbour,

Table 2 First cigarette smoking experience among ever-smoker secondary-school students by age group and sex, Aden Governorate, Republic of Yemen, 1997

\begin{tabular}{lrrrrrr}
\hline Age group & \multicolumn{2}{c}{ Males } & \multicolumn{2}{c}{ Females } & \multicolumn{2}{c}{ Total } \\
(years) & No. & $\%$ & \multicolumn{1}{c}{ No. } & $\%$ & No. & $\%$ \\
\hline$<10$ & 22 & 15.6 & 9 & 16.4 & 31 & 15.8 \\
$10-14$ & 32 & 22.7 & 22 & 40.0 & 54 & 27.5 \\
$15-19$ & 82 & 58.2 & 23 & 41.8 & 105 & 53.6 \\
Not specified & 5 & 3.5 & 1 & 1.8 & 6 & 3.1 \\
Total & 141 & 100.0 & 55 & 100.0 & 196 & 100.0 \\
\hline
\end{tabular}


Table 3 Source of the first cigarette of ever-smoker secondary-school students by sex, Aden Governorate, Republic of Yemen, 1997

\begin{tabular}{lrrrrcrr}
\hline Source & \multicolumn{2}{c}{ Males } & \multicolumn{2}{c}{ Females } & \multicolumn{2}{c}{ Test of statistical } & \multicolumn{2}{c}{ Total } \\
& \multicolumn{1}{c}{ No. } & \multicolumn{1}{c}{$\%$} & No. & $\%$ & ${\text { significance }(Z)^{\mathrm{a}}}^{\mathrm{n}}$ & \multicolumn{1}{c}{ No. } & $\%$ \\
\hline Father & 6 & 4.3 & 16 & 29.1 & $-4.949^{*}$ & 22 & 11.2 \\
Mother & - & - & 7 & 12.7 & - & 7 & 3.6 \\
Sibling & 2 & 1.4 & 10 & 18.2 & $-4.398^{*}$ & 12 & 6.1 \\
Relative/neighbour & 35 & 24.8 & 14 & 25.4 & -0.092 & 49 & 25.0 \\
School friend & 37 & 26.2 & - & - & - & 37 & 18.9 \\
Friend outside school & 32 & 22.7 & 2 & 3.6 & $3.166^{*}$ & 34 & 17.3 \\
Teacher & 5 & 3.6 & - & - & - & 5 & 2.6 \\
Others & 16 & 11.3 & 3 & 5.5 & - & 19 & 9.7 \\
Not specified & 8 & 5.7 & 3 & 5.5 & - & 11 & 5.6 \\
Total & 141 & 100.0 & 55 & 100.0 & - & 196 & 100.0 \\
\hline
\end{tabular}

${ }^{a}$ Hypothesis testing of differences of percentages, two proportions from independent group

"Statistically significant

Table 4 Source of the first cigarette of ever-smoker secondary-school students by age group, Aden Governorate, Republic of Yemen, 1997

\begin{tabular}{|c|c|c|c|c|c|c|c|c|}
\hline \multirow[t]{3}{*}{ Source } & \multicolumn{8}{|c|}{ Age group (years) } \\
\hline & \multicolumn{2}{|c|}{$<10$} & \multicolumn{2}{|c|}{$10-14$} & \multicolumn{2}{|c|}{$15-19$} & \multicolumn{2}{|c|}{$\begin{array}{c}\text { Not } \\
\text { specified }\end{array}$} \\
\hline & No. & $\%$ & No. & $\%$ & No. & $\%$ & No. & $\%$ \\
\hline Father & 10 & 32.3 & 7 & 12.9 & 5 & 4.8 & - & - \\
\hline Mother & - & - & 3 & 5.5 & 4 & 3.8 & - & - \\
\hline Sibling & 4 & 12.9 & 5 & 9.2 & 3 & 2.8 & - & - \\
\hline Relative/neighbour & 17 & 54.8 & 15 & 27.7 & 11 & 10.5 & 6 & 100.0 \\
\hline School friend & - & - & 11 & 20.4 & 26 & 24.8 & - & - \\
\hline Friend outside school & - & - & 7 & 12.9 & 27 & 25.7 & - & - \\
\hline Teacher & - & - & - & - & 5 & 4.8 & - & - \\
\hline Others & - & - & 3 & 5.5 & 16 & 15.2 & - & - \\
\hline Not specified & - & - & 3 & 5.5 & 8 & 7.6 & - & - \\
\hline Total & 31 & 100.0 & 54 & 100.0 & 105 & 100.0 & 6 & 100.0 \\
\hline
\end{tabular}

followed by close relatives (mainly the father) (Table 4). For those starting smoking between 10 years and 14 years the main sources were relative/neighbour, school friend and close relative (father, mother, sibling). For those who started smoking between 15 years and 19 years the main 
Table 5 Place of smoking the first cigarette of ever-smoker secondary-school students by sex, Aden Governorate, Republic of Yemen, 1997

\begin{tabular}{|c|c|c|c|c|c|c|c|}
\hline \multirow[t]{2}{*}{ Place } & \multicolumn{2}{|c|}{ Males } & \multicolumn{2}{|c|}{ Females } & \multirow{2}{*}{$\begin{array}{l}\text { Test of statistical } \\
\text { significance }(Z)\end{array}$} & \multicolumn{2}{|c|}{ Total } \\
\hline & No. & $\%$ & No. & $\%$ & & No. & $\%$ \\
\hline Home & 19 & 13.5 & 43 & 78.2 & $-8.752^{\star}$ & 62 & 31.6 \\
\hline School & 1 & 0.7 & 1 & 1.8 & -0.694 & 2 & 1.0 \\
\hline $\begin{array}{l}\text { On the way to/from } \\
\text { school }\end{array}$ & 35 & 24.8 & 1 & 1.8 & $3.737^{\star}$ & 36 & 18.4 \\
\hline House of friend/relative & 18 & 12.8 & 4 & 7.3 & 1.095 & 22 & 11.2 \\
\hline Not specified & 68 & 48.2 & 6 & 10.9 & - & 74 & 37.8 \\
\hline Total & 141 & 100.0 & 55 & 100.0 & - & 196 & 100.0 \\
\hline
\end{tabular}

*Statistically significant

sources were friends outside school, school friends and others.

It is interesting to note that among those who started smoking at 14 years or younger the first cigarette was predominantly obtaincd at home, bccause the main sources were either close relative or relative/neighbour. Those who started smoking at 15 years or more acquired the habit outside the home, mainly at school or on the streets, i.e. school friends and friends outside school were the main sources. Teachers represented a very small proportion and were only mentioned as a source of the first cigarette by students between 15 years and 19 years. Similar findings were observed by Reimers and colleagues [4]. This indicates that strategies for smoking prevention should not be restricted to individual students but must also cover the student's home and school environment.

The first cigarette was usually smoked at home, followed by on the way to/from school and then at the house of a friend or relative (Table 5). By sex the situation was different. A significantly higher proportion of females reported the home as the place where they started smoking, while a signif- icantly higher proportion of males mentioned starting smoking on the way to/from school (Table 5).

Those who tried the first cigarette at under 10 years old did so in their homes followed by in the house of a friend or relative. Home and the way to/from school were the most common places for the first smoking experience in the age groups 1014 years and $15-19$ years (Table 6).

The reason for starting smoking was usually to see what it was like, i.e. curiosity, followed by to imitate others and then because of encouragement by others (Table 7). The idea that smoking makes people elegant was not a common reason given for starting smoking. By sex the pattern was similar (Table 7). However, the proportion of females who said they started smoking to see what it was like was significantly higher than the proportion of males who gave it that reason.

In all age groups the main reason expressed for starting cigarette smoking was to see what it was like (Table 8). The second reason for the age groups $<10$ years and $10-14$ years was to imitate the behaviour of others, while among the age group 
Table 6 Place of smoking the first cigarette of ever-smoker secondary-school students by age group, Aden Governorate, Republic of Yemen, 1997

\begin{tabular}{|c|c|c|c|c|c|c|c|c|}
\hline \multirow[t]{3}{*}{ Place } & \multicolumn{8}{|c|}{ Age group (years) } \\
\hline & \multicolumn{2}{|c|}{$<10$} & \multicolumn{2}{|c|}{$10-14$} & \multicolumn{2}{|c|}{$15-19$} & \multicolumn{2}{|c|}{ Not specified } \\
\hline & No. & $\%$ & No. & $\%$ & No. & $\%$ & No. & $\%$ \\
\hline Home & 15 & 48.4 & 22 & 40.7 & 23 & 21.9 & 2 & 33.3 \\
\hline School & 1 & 3.2 & - & - & 1 & 0.9 & - & - \\
\hline On the way to/from school & 2 & 6.5 & 13 & 24.1 & 19 & 18.1 & 2 & 33.3 \\
\hline House of friend/relative & 9 & 29.0 & 3 & 5.6 & 9 & 8.6 & 1 & 16.7 \\
\hline Not specified & 4 & 12.9 & 16 & 29.6 & 53 & 50.5 & 1 & 16.7 \\
\hline Total & 31 & 100.0 & 54 & 100.0 & 105 & 100.0 & 6 & 100.0 \\
\hline
\end{tabular}

Table 7 Main reasons for starting smoking of ever-smoker secondary-school students by sex, Aden Governorate, Republic of Yemen, 1997

\begin{tabular}{|c|c|c|c|c|c|c|c|}
\hline \multirow[t]{2}{*}{ Main reason } & \multicolumn{2}{|c|}{ Males } & \multicolumn{2}{|c|}{ Females } & \multirow{2}{*}{$\begin{array}{l}\text { Test of statistical } \\
\text { significance }(Z)\end{array}$} & \multicolumn{2}{|c|}{ Total } \\
\hline & No. & $\%$ & No. & $\%$ & & No. & $\%$ \\
\hline To see what it was like & 75 & 53.2 & 46 & 83.6 & $-3.940^{\star}$ & 121 & 61.7 \\
\hline $\begin{array}{l}\text { To imitate behaviour of } \\
\text { others }\end{array}$ & 18 & 12.8 & 5 & 9.1 & 0.717 & 23 & 11.7 \\
\hline Encouraged by another & $1 /$ & 12.1 & - & - & - & 17 & 8.7 \\
\hline $\begin{array}{l}\text { Smoking makes people } \\
\text { elegant }\end{array}$ & 12 & 8.5 & 3 & 5.5 & 0.723 & 15 & 7.7 \\
\hline Other & 6 & 4.2 & - & - & - & 6 & 3.1 \\
\hline Not specified & 13 & 9.2 & 1 & 1.8 & - & 14 & 7.1 \\
\hline Total & 141 & 100.0 & 55 & 100.0 & - & 196 & 100.0 \\
\hline
\end{tabular}

*Statistically significant

15-19 years it was because of encouragement by others. The third reason given by those under 10 years was that they considered that smoking made people look elegant. This was also the third reason for those aged 10-14 years. Among students who started smoking when they were 15 19 years old the third reason given was to imitate the behaviour of others.
The greatest percentage $(36.3 \%)$ of ever-smoker secondary-school students had their first cigarette with friends/school friends, while $28.6 \%$ had their first cigarette alone (Table 9). Similar findings were reported by Conrad and colleagues, indicating that peer influences are strong predictors of smoking initiation [14]. However, there were statistically significant differences between males and 
Table 8 Main reasons for starting smoking of ever-smoker secondary-school students by age group, Aden Governorate, Republic of Yemen, 1997

\begin{tabular}{|c|c|c|c|c|c|c|c|c|}
\hline \multirow[t]{3}{*}{ Main reason } & \multicolumn{8}{|c|}{ Age group (years) } \\
\hline & \multicolumn{2}{|c|}{$<10$} & \multicolumn{2}{|c|}{$10-14$} & \multicolumn{2}{|c|}{$15-19$} & \multicolumn{2}{|c|}{ Not specified } \\
\hline & No. & $\%$ & No. & $\%$ & No. & $\%$ & No. & $\%$ \\
\hline To see what it was like & 14 & 45.2 & 34 & 63.0 & 71 & 67.7 & 2 & 33.3 \\
\hline $\begin{array}{l}\text { To imitate behaviour of } \\
\text { others }\end{array}$ & 5 & 16.1 & 9 & 16.7 & 9 & 8.6 & - & - \\
\hline Encouraged by another & 1 & 3.2 & 4 & 7.4 & 10 & 9.5 & 2 & 33.3 \\
\hline $\begin{array}{l}\text { Smoking makes people } \\
\text { elegant }\end{array}$ & 2 & 6.5 & 4 & 7.4 & 8 & 7.6 & 1 & 16.7 \\
\hline Other & - & - & 3 & 5.5 & 3 & 2.8 & - & - \\
\hline Not specified & 9 & 29.0 & - & - & 4 & 3.8 & 1 & 16.7 \\
\hline Total & 31 & 100.0 & 54 & 100.0 & 105 & 100.0 & 6 & 100.0 \\
\hline
\end{tabular}

Table 9 Person with whom the first cigarette was smoked of ever-smoker secondary-school students by sex, Aden Governorate, Republic of Yemen, 1997

\begin{tabular}{|c|c|c|c|c|c|c|c|}
\hline \multirow{2}{*}{$\begin{array}{l}\text { Person with whom the } \\
\text { first cigarette was } \\
\text { smoked }\end{array}$} & \multicolumn{2}{|c|}{ Males } & \multicolumn{2}{|c|}{ Females } & \multirow{2}{*}{$\begin{array}{c}\text { Test of } \\
\text { statistical } \\
\text { significance }(Z)^{\mathrm{a}} \\
\end{array}$} & \multicolumn{2}{|c|}{ Total } \\
\hline & No. & $\%$ & No. & $\%$ & & No. & $\%$ \\
\hline Friend/school friend & 64 & 45.4 & 7 & 12.8 & $4.275^{\star}$ & 71 & 36.3 \\
\hline Alone & 35 & 24.8 & 21 & 38.2 & -1.860 & 56 & 28.6 \\
\hline Relative/neighbour & 22 & 15.6 & 3 & 5.4 & 1.914 & 25 & 12.7 \\
\hline Family member & 4 & 2.8 & 21 & 38.2 & $-6.665^{\star}$ & 25 & 12.7 \\
\hline Other & 16 & 11.4 & - & - & - & 16 & 8.2 \\
\hline Not specified & - & - & 3 & 5.4 & - & 3 & 1.5 \\
\hline Total & 141 & 100.0 & 55 & 100.0 & - & 196 & 100.0 \\
\hline
\end{tabular}

aHypothesis testing of difference of percentages, two proportions from independent groups *Statistically significant

females (Table 9). A significantly higher proportion of females were shown to have smoked the first cigarette with a family member, while a significantly higher proportion of males had their first cigarette with a friend/school friend. The other practices had no statistically significant differences by sex.
For students who started smoking at under 10 years of age the highest proportion said that they had their first cigarette alone, followed by in the company of a relative/neighbour and then a family member (Table 10). Among the age group 10-14 years, the first smoking experience took 
Table 10 Person with whom the first cigarette was smoked of ever-smoker secondary-school students by age group, Aden Governorate, Republic of Yemen, 1997

\begin{tabular}{|c|c|c|c|c|c|c|c|c|}
\hline \multirow{3}{*}{$\begin{array}{l}\text { Person with whom the } \\
\text { first cigarette was } \\
\text { smoked }\end{array}$} & \multicolumn{8}{|c|}{ Age group (years) } \\
\hline & \multicolumn{2}{|c|}{$<10$} & \multicolumn{2}{|c|}{$10-14$} & \multicolumn{2}{|c|}{$15-19$} & \multicolumn{2}{|c|}{ Not specified } \\
\hline & No. & $\%$ & No. & $\%$ & No. & $\%$ & No. & $\%$ \\
\hline Friend/school friend & 3 & 9.7 & 18 & 33.3 & 50 & 47.7 & 2 & 33.3 \\
\hline Alone & 14 & 45.2 & 17 & 31.5 & 24 & 22.8 & - & - \\
\hline Relative/neighbour & 9 & 29.0 & 4 & 7.4 & 10 & 9.5 & 2 & 33.3 \\
\hline Family member & 5 & 16.1 & 11 & 20.4 & 8 & 7.6 & - & - \\
\hline Other & - & - & 4 & 7.4 & 11 & 10.5 & 1 & 16.7 \\
\hline Not specified & - & - & - & - & 2 & 1.9 & 1 & 16.7 \\
\hline Total & 31 & 100.0 & 54 & 100.0 & 105 & 100.0 & 6 & 100.0 \\
\hline
\end{tabular}

place with friend/school friend $(33.3 \%)$, alone $(31.5 \%)$ and with a family member $(20.4 \%)$.

\section{Conclusions}

- The smoking prevalence among secondary-school students in Aden Governorate was higher among males than females.

- A significantly higher proportion of girls than boys started smoking at age 14 years or less.

- The main sources for the first cigarette wore significantly different between boys and girls. For boys the sources were friends outside school and school friends, while for girls they were the close relatives, i.e. father, mother or sibling.

- The most common place for smoking the first cigarette for those aged 14 years or under was the home, while for males aged 15-19 years it was outside the home. The place of smoking the first cigarette was significantly different be- tween girls and boys; girls predominantly smoked their first cigarette at home, while boys had this experience on the way to/from school.

- The main reason for starting smoking was to see what it was like but a significantly higher proportion of girls than boys gave this as the reason. Among those aged 14 years or under the second reason expressed was to imitate the behaviour of others, while among the age group 15-19 years it was because of encouragement by others.

- The first cigarelte was smoked in different company depending on the sex and the difference was significant. Girls reported the company of a family member and boys mentioned a friend/school friend. In those aged under 10 years, the first cigarette was generally smoked alone; among those aged 10 years or more it was smoked predominantly in the company a friend/school friend.

- Smoking prevention strategies should involve home, school and social environments as well as the students themselves. 


\section{References}

1. Yemen Association for Cancer Control. Smoking: why we need to leave smoking and how we can succeed. Sana'a, Republic of Yemen, Horizons Printing and Publishing, 1995.

2. Kartasasmita $C B$ et al. Risk factors in smoking habits of high-school students. Paediatrica Indonesiana, 1990, 30(12):31-41.

3. Zhu-BP et al. Cigarette smoking and its risk factors among elementary school students in Beijing. American journal of public health, 1996, 86(3):368-75.

4. Reimers TM et al. Risk factors for adolescent cigarette smoking. The Muscatine study. American journal of diseases of children, 1990, 144(11):1265-72.

5. Johnson EH, Gilbert D. Familial and psychological correlates of smoking in black and white adolescents. Ethnicity and disease, 1991, 1(4):320-34.

6. World Health Organization Office of Information. Public places and transport better be tobacco-free. Geneva, World Health Organization, 1991 (WHO features No. 157).

7. Bawazeer AA et al. Smoking habits among secondary school students and teachers, Aden Governorate, course 1991. In: Proceedings of the 13th Scientific Session, Faculty of Medicine, Aden University. Aden, Republic of Yemen, Aden University Press, 1993.

8. Bawazeer AA et al. Chewing khat and associated habits among medical stu- dents, Aden, University of Aden, Faculty of Medicine, Aden, 1991. In: Proceedings of the 13th Scientific Session, Faculty of Medicine, Aden University. Aden, Republic of Yemen, Aden University Press, 1993.

9. Jarallah JS et al. Predictors of smoking among male junior secondary school students in Riyadh, Saudi Arabia. Tobacco control, 1996, 5(1):26-9.

10. Salehi SO, Elder NC. Prevalence of cigarette and smokeless tobacco use among students in rural Oregon. Family medicine, 1995, 27(2):122-5.

11. Ford DJ et al. A national survey of cigarette smoking in fourth-form school children in New Zealand. New Zealand medical journal, 1995, 108(1011):454-7.

12. Zhu BP et al. Cigarette smoking among junior high school students in Beijing, China, 1988. International journal of epidemiology, 1992, 21(5):854-61.

13. Maglion T et al. Prevelenza dell' abitudine al fumo tra gli studenti di 3 media Benevento. [Prevalence of smoking habits among secondary school students in Benevento.] Epidemiologica $e$ prevenzione, 1994, 18(61):237-40.

14. Conrad KM, Fly BR, Hill D. Why children start smoking cigarettes: predictors of onset. British journal of addiction, 1992, 87:1711-24. 